
cited.

\title{
PEDOMAN PERATURAN PERUNDANG-UNDANGAN DI INDONESIA: PERAN INDEKS INTERNASIONAL
}

\author{
Handa S. Abidin \\ (Dosen Program Studi Ilmu Hukum Universitas Presiden. Memperoleh gelar Sarjana Hukum (S.H.) dari Universitas Indonesia (2007), Master of \\ Laws (LL.M.) dari the George Washington University (2010), dan Doctor of Philosophy (Ph.D.) dari the University of Edinburgh (2014)) \\ (E-mail: handa.abidin@ president.ac.id)
}

Received: 16 Februari 2018; Accepted: 5 September 2018; Published: 19 September 2018

\begin{abstract}
:
There are a number of positive impacts if Indonesia uses these three indexes: the World Bank's Ease of Doing Business, the World Economic Forum's Global Competitiveness Index, and the World Justice Project's Rule of Law Index as guidance for "peraturan perundang-undangan" (laws and regulations). Nonetheless, it is important to note that there are also negative impacts that could arise. One of the important solutions to avoid negative impacts is to consistently comply with Pancasila and the 1945 Constitution of the State of the Republic of Indonesia. The concept of using international indexes as guidance is not only limited to the Ease of Doing Business, the Global Competitiveness Index, and the Rule of Law Index. Other relevant international indexes could have also roles in providing guidance for laws and regulations in Indonesia, by taking into account the discussion and recommendations in this research, in particular: these indexes must be in accordance with Pancasila and the 1945 Constitution of the State of the Republic of Indonesia. Furthermore, this research also provides recommendations for how to improve Indonesia's rankings on the three indexes, which could also be relevant in the context of other international indexes.
\end{abstract}

Keywords: Indonesia, laws and regulations, ease of doing business, global competitiveness index, rule of law index.

\section{Pendahuluan}

Pancasila dalam Pasal 2 Undang-

Undang Republik Indonesia Nomor 12

Tahun 2011 tentang Pembentukan Peraturan

Perundang-undangan (“UU 12/2011”) dinyatakan sebagai: "sumber segala sumber hukum negara."1 Hal ini mengikuti apa yang

\footnotetext{
1 Undang-Undang Republik Indonesia Nomor 12 Tahun 2011 tentang Pembentukan Peraturan Perundang-undangan (Disahkan: 12 Agustus 2011 Diundangkan: 12 Agustus 2011) (“UU 12/2011”) Pasal 2 dan Penjelasan Pasal 2.
}

sudah dijelaskan oleh Alinea Keempat Pembukaan Undang-Undang Dasar Negara Republik Indonesia Tahun 1945 ("UUD NRI 1945") ${ }^{2}$ yang menyatakan Pancasila merupakan dasar bagi Indonesia. ${ }^{3}$ Pancasila merupakan "dasar dan ideologi negara" dan

\footnotetext{
2 Ibid, UU/12/2011, Penjelasan Pasal 2.

${ }^{3}$ Undang-Undang Dasar Negara Republik Indonesia Tahun 1945, Pembukaan, Alinea Keempat <http://www.dp r.go.id/jdih/uu1945> diakses tanggal 6 Januari 2018.
} 


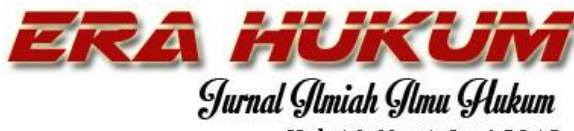

Vol 16, No. 1, Juni 2018

"dasar filosofis negara". ${ }^{4}$ Oleh karena karakteristik Pancasila sebagaimana disebutkan di atas, peraturan perundangundangan kita wajib berpedoman ${ }^{5}$ pada Pancasila dan tidak boleh bertolak belakang dengan Pancasila. ${ }^{6}$

Pada Pasal 3 ayat (1) UU 12/2011, UUD NRI 1945 dinyatakan sebagai "hukum dasar" yang menjadi pedoman peraturan perundang-undangan. ${ }^{7}$ Dengan kata lain dalam konteks pembentukan peraturan perundang-undangan di bawah UUD NRI 1945, UUD NRI 1945 berperan sebagai "norma dasar" dan "sumber hukum".

Baik Pancasila maupun UUD NRI 1945 merupakan fondasi dari sistem hukum nasional. ${ }^{9}$ "Sistem" dapat didefinisikan sebagai: "perangkat unsur yang secara teratur saling berkaitan sehingga membentuk suatu totalitas." Astawa dan Suprin Na'a mengatakan sistem merupakan "kesatuan yang terdiri dari

\footnotetext{
${ }^{4}$ UU/12/2011 (n 1) Penjelasan Pasal 2.

5 Untuk definisi, "pedoman", lihat: Badan Pengembangan dan Pembinaan Bahasa, Kementerian Pendidikan dan Kebudayaan Republik Indonesia (KBBI Daring), "Pe.do.man /pêdoman/" <https://kbbi.kemdikbud.go.id/entri/p edoman> diakses tanggal 9 Desember 2017.

${ }^{6}$ UU/12/2011 (n 1) Pasal 2 dan Penjelasan Pasal 2.

${ }^{7}$ Ibid, Pasal 3 ayat (1).

${ }^{8}$ Ibid, Penjelasan Pasal 3 ayat (1).

${ }^{9}$ Ibid, Penjelasan Pasal 17.

10 Badan Pengembangan dan Pembinaan Bahasa, Kementerian Pendidikan dan Kebudayaan Republik
}

Handa S. Abidin Pedoman Peraturan Perundang-undangan..

unsur-unsur (subsistem-subsistem)" yang ingin "mencapai tujuan tertentu". ${ }^{11}$ UU 12/2011 mendefinisikan "sistem hukum nasional" sebagai:

"[S]istem hukum yang berlaku di Indonesia dengan semua elemennya serta saling menunjang satu dengan yang lain dalam rangka mengantisipasi dan mengatasi permasalahan yang timbul dalam kehidupan berbangsa, bernegara, dan bermasyarakat." 12

Tentunya sistem hukum nasional yang didefinisikan pada UU 12/2011 beserta semua elemennya berpatokan pada Pancasila dan UUD NRI $1945 .{ }^{13}$

Maria Farida Indrati mengklasifikasikan Pancasila sebagai "norma fundamental negara (staatsfundamentalnorm)" sekaligus "cita hukum" dan Batang Tubuh UUD [NRI] 1945 sebagai "aturan dasar negara / aturan pokok negara (verfassungsnorm)". ${ }^{14}$ Solly

Indonesia (KBBI Daring), "Sis.tem /sistém/" <https://kbbi.kemdikbud.go.id/entri/sistem> diakses tanggal 14 Januari 2018.

${ }^{11}$ M. I Gde Pantja Astawa dan Supri Na'a, Dinamika Hukum dan Ilmu Perundang-undangan di Indonesia (PT Alumni, Cetakan ke-2, 2012) 41. Untuk pembahasan mengenai definisi "sistem" dan "sistem hukum", lihat: 40- 47.

12 UU/12/2011 (n 1) Penjelasan Pasal 17.

${ }^{13}$ Ibid.

${ }^{14}$ Maria Farida Indrati S., Ilmu Perundang-undangan

(1) (Jenis, Fungsi, dan Materi Muatan) (Dikembangkan dari Perkuliahan A. Hamid S. 


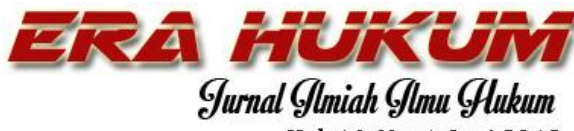

Vol 16, No. 1, Juni 2018

Lubis mengatakan Pancasila merupakan "tolak ukur dan batu penguji" untuk menilai apakah suatu hukum sudah baik atau tidak. ${ }^{15}$ Mengenai Pancasila dan UUD NRI 1945, Presiden Joko Widodo ("Presiden Jokowi”) pernah mengatakan perlu dipastikan peraturan perundang-undangan yang ada sesuai dengan Pancasila dan UUD NRI 1945. ${ }^{16}$ Presiden Jokowi juga pernah menyatakan Pancasila jangan hanya dijadikan "slogan semata" saja, akan tetapi Pancasila harus direalisasikan. ${ }^{17}$

Pada prinsipnya "peraturan perundangundangan" dalam konteks penelitian ini adalah berdasarkan Pasal 1 angka 2 dengan dikaitkan pada Pasal 7 dan 8 UU 12/2011. Menurut Pasal 1 angka 2 UU 12/2011:

Attamimi) (Kanisius 2007) 59, lihat juga: 57-58, 6568, dan 262-263.

15 M. Solly Lubis, Ilmu Pengetahuan Perundangundangan (CV Mandar Maju 2009) 89.

16 Sekretariat Kabinet Republik Indonesia, "Pengantar Presiden Joko Widodo pada Rapat Terbatas [M]engenai Lanjutan Pembahasan Reformasi Hukum, 17 Januari 2017, di Kantor Presiden, Jakarta" (17 Januari 2017) <http: //setkab.go.id/pengantar-presiden-joko-widodopada-rapat-terbatas-mengenai-lanjutan-pembahasanreformasi-h ukum-17-januari-2017-di-kantorpresiden-jakarta/> diakses tanggal 11 Desember 2017.

17 Sekretariat Kabinet Republik Indonesia, "Pengantar Presiden Joko Widodo pada Rapat Terbatas [M]engenai Pemantapan Pancasila, 19 Desember 2016, di Kantor Presiden, Jakarta" (19 Desember 2016) <http://setkab.go.i d/pengantarpresiden-joko-widodo-pada-rapat-terbatasmengenai-pemantapan-pancasila-19-desember2016-di-k antor-presiden-jakarta/> diakses tanggal 6 Januari 2017. Pada bulan Mei 2017 telah dibentuk
Handa S. Abidin

Pedoman Peraturan Perundang-undangan..
"Peraturan Perundang-undangan adalah peraturan tertulis yang memuat norma hukum yang mengikat secara umum dan dibentuk atau ditetapkan oleh lembaga negara atau pejabat yang berwenang melalui prosedur yang ditetapkan dalam Peraturan Perundangundangan." 18

Jenis dan hierarki peraturan perundangan-undangan diatur oleh Pasal 7 ayat (1) UU 12/2011 yaitu sebagai berikut:

“a. Undang-Undang Dasar Negara Republik Indonesia Tahun 1945; b. Ketetapan Majelis Permusyawaratan Rakyat; c. UndangUndang/Peraturan Pemerintah Pengganti Undang-Undang; d. Peraturan Pemerintah; e. Peraturan

Unit Kerja Presiden Pembinaan Ideologi Pancasila yang bertugas antara lain membantu Presiden dalam pembinaan ideologi Pancasila, lihat: Peraturan Presiden Republik Indonesia Nomor 54 Tahun 2017 tentang Unit Kerja Presiden Pembinaan Ideologi Pancasila (Ditetapkan: 19 Mei 2017 | Diundangkan: 23 Mei 2017) Pasal 3.

18 UU 12/2011 (n 1) Pasal 1 angka 2. Lihat juga definisi peraturan perundang-undangan oleh Bagir Manan, lihat: Indrati S., Ilmu Perundang-undangan (1) (Jenis, Fungsi, dan Materi Muatan) (n 14) 10-11. Lihat juga kritikan Maria Farida Indrati S. terhadap definisi peraturan perundang-undangan berdasarkan Undang-Undang Republik Indonesia Nomor 10 Tahun 2004 tentang Pembentukan Peraturan Perundang-undangan ("UU 10/2004") (telah "dicabut dan dinyatakan tidak berlaku" oleh UU 12/2011), lihat: (1) Indrati S., Ilmu Perundangundangan (1) (Jenis, Fungsi, dan Materi Muatan) (n 14) 12-13, lalu: 29-30; dan (2) UU 12/2011, Pasal 102. Walaupun UU 10/2004 tidak berlaku lagi, namun kritikan Maria Farida Indrati masih relevan dalam konteks UU 12/2011. 
Presiden; f. Peraturan Daerah Provinsi; dan g. Peraturan Daerah Kabupaten/Kota."19

Selain jenis peraturan perundangundangan pada Pasal 7 ayat (1) di atas, Pasal 8 ayat (1) UU 12/2011 mengatur sebagai berikut:

"Jenis Peraturan Perundangundangan selain sebagaimana dimaksud dalam Pasal 7 ayat (1) mencakup peraturan yang ditetapkan oleh Majelis Permusyawaratan Rakyat, Dewan Perwakilan Rakyat, Dewan Perwakilan Daerah, Mahkamah Agung, Mahkamah Konstitusi, Badan Pemeriksa Keuangan, Komisi Yudisial, Bank Indonesia, Menteri, badan, lembaga, atau komisi yang setingkat yang dibentuk dengan Undang-Undang atau Pemerintah atas perintah Undang-Undang, Dewan Perwakilan Rakyat Daerah Provinsi, Gubernur, Dewan Perwakilan Rakyat Daerah Kabupaten/Kota, Bupati/Walikota, Kepala Desa atau yang setingkat." ${ }^{20}$

Maria Farida Indrati menyatakan penempatan UUD NRI 1945 dalam

19 Ibid, UU 12/2011, Pasal 7 ayat (1). Untuk pembahasan perbedaan teori jenjang norma Hans Kelsen dan teori jenjang norma hukum Hans Nawiasky, lihat: Ibid, Indrati S., Ilmu Perundangundangan (1) (Jenis, Fungsi, dan Materi Muatan), 47.

${ }^{20}$ Ibid, UU 12/2011, Pasal 8 ayat (1). Lihat juga: Pasal 8 ayat (2).

${ }^{21}$ Indrati S., Ilmu Perundang-undangan (1) (Jenis, Fungsi, dan Materi Muatan) (n 14) 99-100. Kritikan klasifikasi peraturan perundang-undangan “terlalu rendah" dan "tidak tepat". ${ }^{21}$ Hal ini dikarenakan Pembukaan UUD NRI 1945 diklasifikasikan sebagai "norma fundamental negara" yang merupakan "norma hukum tertinggi" di Indonesia. ${ }^{22}$ Sedangkan Batang Tubuh UUD NRI 1945 diklasifikasikan sebagai "aturan dasar negara / aturan pokok negara" yaitu "garisgaris besar atau pokok-pokok kebijaksanaan negara" Indonesia. ${ }^{23}$

Oleh karena itu penting untuk digarisbawahi dalam konteks penelitian ini apabila terdapat kalimat yang kurang lebih mengatakan "peraturan perundangundangan harus berpedoman pada UUD NRI 1945", maka hal ini harus diartikan bahwa "peraturan perundang-undangan" tersebut adalah seluruh peraturan perundang-undangan yang berada di bawah UUD NRI 1945. Hal ini perlu dilakukan demi mencegah pandangan mengapa UUD NRI 1945 harus berpedoman kepada UUD NRI 1945 mengingat UUD NRI 1945 juga

Maria Farida Indrati adalah dalam konteks UU 10/2004, namun demikian kritikan tersebut masih relevan dalam konteks UU 12/2011. Untuk pendapat yang setuju untuk mengklasifikasikan UUD NRI 1945 sebagai peraturan perundang-undangan, lihat: Astawa dan Na'a (n 11) 58-59.

22 Ibid, Indrati S., Ilmu Perundang-undangan (1) (Jenis, Fungsi, dan Materi Muatan), 99-100.

${ }^{23}$ Ibid. 


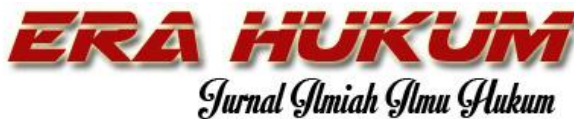

Vol 16, No. 1, Juni 2018

Handa S. Abidin Pedoman Peraturan Perundang-undangan..

dimasukkan dalam hierarki peraturan perundang-undangan dalam UU 12/2011 sebagaimana dijelaskan di atas.

Sepanjang tidak bertentangan dengan Pancasila dan UUD NRI $1945 \operatorname{arah}^{24}$ pengelolaan peraturan perundang-undangan di Indonesia dapat juga berpedoman pada indeks yang diakui secara internasional. Menurut Oxford Dictionaries "index" dapat didefinisikan sebagai " $[a]$ sign or measure of something." 25 Pengelolaan peraturan perundang-undangan dalam konteks ini dilakukan dengan arah menuju peringkat

${ }^{24}$ Untuk definisi "arah", lihat: Badan Pengembangan
dan Pembinaan Bahasa, Kementerian Pendidikan dan
Kebudayaan Republik Indonesia (KBBI Daring),
"Arah" <https://kbbi.kemdikbud.go.id/entri/arah>
diakses tanggal 6 Januari 2018.
${ }_{25}$ Oxford "index" <https://en.oxforddictionaries.com/definition/index> diakses tanggal 7 Januari 2018.

26 "World Bank" merupakan bagian dari "World Bank Group". Untuk penjelasan mengenai World Bank dan World Bank Group, lihat: World Bank, A Guide to the World Bank (World Bank, $3^{\text {rd }}$ Edition, 2011) 2 dan 10-11.

${ }^{27}$ Misalnya, lihat: (1) Sekretariat Kabinet Republik Indonesia, "Intervensi Presiden RI Joko Widodo [p]ada KTT G-20, di Brisbane, Australia, 15 November 2014" (16 November 2014) $<$ http://setkab.go.id/intervensi-pres iden-ri-joko-widodo-pada-ktt-g-20-di-brisbaneaustralia-15-november-2014/> diakses tanggal 12 Desember 2017; (2) Sekretariat Kabinet Republik Indonesia, "Pengantar Presiden Joko Widodo pada Rapat Terbatas Masalah Ease of Doing Business [sic!] di Kantor Presiden, Jakarta, 20 Januari 2016" (20 Januari 2016) <http://setkab.go.id/pengantarpresiden-joko-widodo-pada-rapat-terbatas-masalahease-of-doing-business-di-ka ntor-presiden-jakarta-20-januari-2016/> diakses tanggal 11 Desember 2017; (3) Sekretariat Kabinet Republik Indonesia, "Pengantar Presiden Joko yang lebih baik dalam indeks internasional tersebut dengan tujuan yang sesuai dengan Pancasila dan UUD NRI 1945.

Presiden Jokowi telah menaruh perhatian khusus untuk meningkatkan peringkat Ease of Doing Business (laporan Doing Business) yang dimotori oleh World Bank $^{26}$ dengan membahasnya pada sejumlah pidatonya. ${ }^{27}$ Presiden Jokowi berulang kali mengatakan Indonesia memiliki target duduk di peringkat 40 besar Ease of Doing Business. ${ }^{28}$ Dapat dikatakan peringkat Ease of Doing Business

Widodo [p]ada Rapat Terbatas Mengenai Ease of Doing Business [sic!], 9 Mei 2016 Pukul 15.00 WIB, di Kantor Presiden Jakarta" (9 Mei 2016) $<$ http://setkab.go.id/pengantar-presiden-j oko-widodo-pada-rapat-terbatas-mengenai-ease-ofdoing-business-9-mei-2016-pukul-15-00-wib-dikantor-presi

den-jakarta/> diakses tanggal 11 Desember 2017; dan (4) Sekretariat Kabinet Republik Indonesia, "Pengantar Presiden Joko Widodo pada Sidang Kabinet Paripurna tentang Kapasitas Fiskal (Resource Envelopes) [sic!] dan Pagu Indikatif RAPBN Tahun 2018 serta Peningkatan Peringkat Ease of Doing Business [sic!] (EoDB) Tahun 2018, di Istana Negara, Jakarta, 15 Maret 2017" (15 Maret 2017) <http://setkab.go.id/pengantar-presiden-jokowidodo-pada-sidang-kabinet-paripur na-tentangkapasitas-fiskal-resource-envelopes-dan-paguindikatif-rapbn-t

ahun-2018-serta-peningkatan-peringk at-ease-ofdoing-business-eodb/> diakses tanggal 11 Desember 2017.

${ }^{28}$ Misalnya: Sekretariat Kabinet Republik Indonesia, "Sambutan Presiden Joko Widodo saat Pencatatan Perdana Kontrak Investasi Kolektif - Efek Beragun Aset (KIK - EBA) Mandiri - PT Jasa Marga, Tbk. (JSMR 01) Surat Berharga Hak Atas Pendapatan Tol Jagorawi, Kamis, 31 Agustus 2017 Pukul 08.30 WIB di Gedung Bursa Efek Indonesia (BEI), Jakarta" (31 
merupakan indeks internasional yang menjadi salah satu ukuran keberhasilan pemerintah di bawah pimpinan Presiden Jokowi.

Selain Indonesia, negara lain juga menganggap peringkat Ease of Doing Business sebagai hal yang penting untuk diperhatikan. ${ }^{29}$ Kristalina Georgieva, Chief Executive Officer dari World Bank, mengatakan lebih dari 60 perekonomian dalam 1 dekade terakhir membentuk komite reformasi regulasi berpatokan pada indikator Doing Business. ${ }^{30}$ Selanjutnya Kristalina Georgieva menyatakan pemerintah dari berbagai perekonomian melaporkan telah melakukan 3.180

Agustus 2017) <http://setkab.go.id/sambutanpresiden-joko-widodo-saat-pencatat an-perdana-kontrak-investasi-kolektif-efek-beragunaset-kik-eba-mandiri-pt-jasa-marga-tbk-jsmr-01surat-berha

rga-hak-atas/> diakses tanggal 12 Desember 2017.

${ }^{29}$ World Bank, Doing Business 2018 | Reforming to Create Jobs (International Bank for Reconstruction and Development / the World Bank) Foreword.

${ }^{30}$ Ibid.

${ }^{31}$ Ibid.

${ }^{32}$ Lihat: (1) World Bank, Doing Business 2017 | Equal Opportunity for All (International Bank for Reconstruction and Development / the World Bank) 7; dan (2) World Bank, Doing Business 2018 | Reforming to Create Jobs (n 29) 4.

${ }^{33}$ Ibid.

${ }^{34}$ Lihat: (1) World Bank, Doing Business in 2006 Creating Jobs (International Bank for Reconstruction and Development / the World Bank) (Copublication of the World Bank dan the International Finance Corporation) 92; (2) World Bank, Doing Business 2007 How to Reform (International Bank for Reconstruction and Development / the World Bank) (Copublication of the World Bank and the reformasi regulasi, termasuk 920 reformasi regulasi yang dilakukan dikarenakan terinspirasi dari laporan Doing Business. ${ }^{31}$

Pada masa pemerintahan Presiden Jokowi, Indonesia berhasil menembus peringkat 100 besar Ease of Doing Business pada laporan Doing Business World Bank 2017 dan 2018. ${ }^{32}$ Pada laporan Doing Business World Bank 2017 Indonesia menduduki peringkat 91 dan pada laporan Doing Business World Bank 2018 Indonesia berada peringkat $72 .{ }^{33}$ Posisi 72 ini merupakan peringkat terbaik Indonesia sepanjang laporan Doing Business World Bank. ${ }^{34}$ Pada tahun-tahun sebelumnya peringkat Indonesia mengalami pasang

International Finance Corporation) 6; (3) World Bank, Doing Business 2008 (International Bank for Reconstruction and Development / the World Bank) (Copublication of the World Bank dan the International Finance Corporation) 7; (4) World Bank, Doing Business 2009 (International Bank for Reconstruction and Development / the World Bank) (Copublication of the World Bank, the International Finance Corporation, dan Palgrave Macmillan) 6; (5) World Bank, Doing Business 2010 | Reforming Through Difficult Times (International Bank for Reconstruction and Development / the World Bank) (Copublication of the Palgrave Macmillan, the World Bank dan the International Finance Corporation) 4; (6) World Bank, Doing Business 2011 | Making a Difference for Entrepreneurs (International Bank for Reconstruction and Development / the World Bank) (Copublication of the World Bank dan the International Finance Corporation) 4; (7) World Bank, Doing Business 2012 | Doing Business in More Transparent World (International Bank for Reconstruction and Development / the World Bank) (Copublication of the World Bank dan the International Finance Corporation) 6; (8) World Bank, Doing Business 2013 | Smarter Regulations for 
surut pada posisi di atas 100 besar. ${ }^{35}$ Perbaikan peringkat ini merupakan hasil antara lain upaya perubahan dan penyederhanaan peraturan yang digalakkan oleh pemerintah di berbagai bidang yang semakin mempermudah kemudahan untuk melakukan suatu bisnis di Indonesia. ${ }^{36}$

Indeks internasional lainnya yang dapat digunakan sebagai pedoman, misalnya seperti Global Competitiveness Index Rankings 2017-2018 yang memosisikan Indonesia pada peringkat $36 .{ }^{37}$ Presiden

Small and Medium-Size Enterprises (International Bank for Reconstruction and Development / the World Bank) (Copublication of the World Bank dan the International Finance Corporation) 3; (9) World Bank, Doing Business 2014 | Understanding Regulations for Small and Medium-Size Enterprises (International Bank for Reconstruction and Development / the World Bank) (Copublication of the World Bank dan the International Finance Corporation) 3; (10) World Bank, Doing Business 2015 | Going Beyond Efficiency (International Bank for Reconstruction and Development / the World Bank) 4; (11) World Bank, Doing Business 2016 | Measuring Regulatory Quality and Efficiency (International Bank for Reconstruction and Development / the World Bank) 5; dan (12) Ibid. Lihat secara umum: (1) World Bank, Doing Business in 2004 | Understanding Regulation (International Bank for Reconstruction and Development / the World Bank) (Copublication of the World Bank, the International Finance Corporation, dan Oxford University Press); dan (2) World Bank, Doing Business in 2005 | Removing Obstacles to Growth (International Bank for Reconstruction and Development / the World Bank) (Copublication of the World Bank, the International Finance Corporation, dan Oxford University Press). Lihat juga secara umum seluruh Laporan World Bank (subnational report) mengenai Doing Business di Indonesia.

${ }^{35}$ Ibid.
Jokowi pernah menyatakan Global Competitiveness Index (Indeks Daya Saing Global) Indonesia yang masih tertinggal dibandingkan Singapura, Malaysia, dan Thailand; oleh karena itu Indonesia perlu melakukan penguatan daya saing globalnya. ${ }^{38}$ Selain itu terdapat juga Rule of Law Index yang pernah Presiden Jokowi singgung ketika membahas hukum di Indonesia yang menurut Presiden Jokowi

${ }^{36}$ Lihat: (1) World Bank Group, Doing Business 2018 | Reforming to Create Jobs | Economy Profile Indonesia (World Bank Group) 132-134; (2) Sekretariat Kabinet Republik Indonesia, "Pengantar Presiden Joko Widodo pada Rapat Terbatas Masalah Ease of Doing Business [sic!] di Kantor Presiden, Jakarta, 20 Januari 2016" (n 27); (3) Sekretariat Kabinet Republik Indonesia, "Pengantar Presiden Joko Widodo [p]ada Rapat Terbatas Mengenai Ease of Doing Business [sic!], 9 Mei 2016 Pukul 15.00 WIB, di Kantor Presiden Jakarta" (n 27); dan (4) Sekretariat Kabinet Republik Indonesia, "Pengantar Presiden Joko Widodo pada Sidang Kabinet Paripurna tentang Kapasitas Fiskal (Resource Envelopes) [sic!] dan Pagu Indikatif RAPBN Tahun 2018 serta Peningkatan Peringkat Ease of Doing Business [sic!] (EoDB) Tahun 2018, di Istana Negara, Jakarta, 15 Maret 2017”' (n 27).

37 World Economic Forum, The Global Competitiveness Report 2017-2018 (World Economic Forum 2017) 13.

38 Sekretariat Kabinet Republik Indonesia, "Sambutan Presiden Joko Widodo pada Jambore HIMPI [sic!] Perguruan Tinggi se-ASEAN, Senin, 23 Mei 2016 pukul 10.00 WIB, di Telkom University, Bandung, Jawa Barat" (23 Mei 2016) $<$ http://setkab.go.id/sambutan-presiden-jokowidodo-pada-jambore-himpi-perguruan-ting gi-seasean-senin-23-mei-2016-pukul-10-00-wib-ditelkom-university-bandung-jawa-barat/> diakses tanggal 7 Januari 2018. 


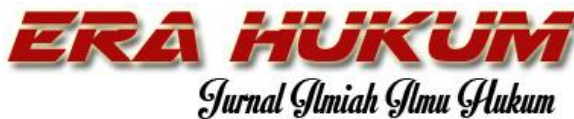

Vol 16, No. 1, Juni 2018 masih tidak adil. ${ }^{39}$ Pada Rule of Law Index 2017-2018 Indonesia berada di posisi 63.40

Masih terdapat indeks internasional lainnya yang relevan dengan Indonesia misalnya seperti Human Development Index (“HDI”) dari United Nations Development Programme (UNDP) di mana Indonesia menduduki peringkat 113 dalam Human Development Report $2016 .{ }^{41}$ Indeks lain seperti Corruption Perceptions Index 2016 menempatkan Indonesia di peringkat $90,{ }^{42}$ World Happiness Report memosisikan Indonesia di urutan 81 (2014-2016), ${ }^{43}$ dan Economic Freedom of the World meletakkan Indonesia di peringkat 73 (2015). ${ }^{44}$

39 Sekretariat Kabinet Republik Indonesia, "Pengantar Presiden Rapat Terbatas tentang Reformasi Hukum di Kantor Presiden, Selasa $(11 / 10) " \quad(11 \quad$ Oktober 2016) $<$ http://setkab.go.id/pengantar-presiden-rapatterbatas-tenta ng-reformasi-hukum-di-kantorpresiden-selasa-1110/> diakses tanggal 12 Desember 2017.

${ }^{40}$ World Justice Project, World Justice Project Rule of Law Index 2017-2018 (World Justice Project 2018) 3 dan 91.

41 Lihat: (1) United Nations Development Programme, Human Development Report 2016 Human Development for Everyone (United Nations Development Programme 2016) 199; dan (2) United Nations Development Programme, "Indonesia, Human Development Indicators" <http://hdr.undp.org/en/countries/profiles/IDN> diakses tanggal 10 Desember 2017.

42 Transparency International, "Corruption Perceptions Index 2016" (Transparency International 2017).

${ }^{43}$ John Helliwell, Richard Layard, dan Jeffrey Sachs (editor), World Happiness Report 2017 (Sustainable Development Solutions Network 2017) 21.
Handa S. Abidin Pedoman Peraturan Perundang-undangan..

Terdapat juga indeks internasional spesifik per sektor tertentu, misalnya dalam konteks sektor pariwisata terdapat indeks yang bernama the Travel \& Tourism Competitiveness Index 2017 Ranking dari the World Economic Forum ${ }^{45}$ di mana Kementerian Pariwisata juga telah berpedoman pada peringkat ini dalam mengukur kinerjanya. ${ }^{46}$ Pada the Travel \& Tourism Competitiveness Index 2017 Ranking tersebut Indonesia duduk di posisi 42. ${ }^{47}$

Saat ini terdapat 34 kementerian $^{48}$ dan berbagai lembaga, seperti lembaga setingkat menteri dan lembaga lain ${ }^{49}$, lembaga non-

\footnotetext{
44 James Gwartney, Robert Lawson, dan Joshua Hall, Economic Freedom of the World 2017 - Annual Report (Fraser Institute 2017) 7 dan 96.

45 World Economic Forum, The Travel \& Tourism Competitiveness Report 2017 - Paving the Way for a More Sustainable and Inclusive Future (World Economic Forum 2017) 9.

46 Kementerian Pariwisata Republik Indonesia, "[']Siaran Pers['] Menpar Arief Yahya Membuka Wonderful Indonesia Co-Branding Forum (WICF)" (11 Agustus 2017) <http://www.kemenpar.go.id/asp/detil.asp?c=16\&id $=3707>$ diakses tanggal 10 Desember 2017 .

47 World Economic Forum, The Travel \& Tourism Competitiveness Report 2017 - Paving the Way for a More Sustainable and Inclusive Future (n 45) 9.

${ }^{48}$ Kementerian Pendayagunaan Aparatur Negara dan Reformasi Birokrasi Republik Indonesia, "Kementerian" <https://www.menpan.go.id/site/kelembagaan/7577kementerian-2> diakses tanggal 10 Desember 2017.

${ }^{49}$ Kementerian Pendayagunaan Aparatur Negara dan Reformasi Birokrasi Republik Indonesia, "Lembaga Setingkat Menteri dan Lembaga Lain"
} 
struktural $^{50}$, lembaga pemerintah nonkementerian $^{51}$, serta lembaga negara lain di luar pemerintah ${ }^{52} .{ }^{53}$ Idealnya kementerian dan lembaga ini juga dapat mengikuti langkah yang dilakukan Kementerian Pariwisata dengan mencari indeks internasional spesifik yang dapat dijadikan pedoman dalam mengukur kinerjanya secara internasional di samping memperbaiki peringkat pada indeks internasional yang umum. Termasuk dengan membuat peraturan perundang-undangan dan produk hukum terkait regulasi di luar peraturan perundang-undangan yang mendukung peningkatan peringkat pada indeks tersebut tanpa melupakan Pancasila

<https://www.menpan.go.id/site/kelembagaan/547lembaga-setingkat-me

nteri-dan-lembaga-lain> diakses tanggal 10 Desember 2017.

${ }^{50}$ Kementerian Pendayagunaan Aparatur Negara dan Reformasi Birokrasi Republik Indonesia, "Lembaga Non Struktural" $<$ https://www.menpan.go.id/site/kelembagaan/7571lembaga-non-struktural-2> diakses tanggal 10 Desember 2017.

${ }^{51}$ Kementerian Pendayagunaan Aparatur Negara dan Reformasi Birokrasi Republik Indonesia, "E. Lembaga Pemerintah Non Kementerian" <https://www.menpan.go.id/site/kelembagaan/7561lembaga-pemerintah-non-kementerian-2> diakses tanggal 10 Desember 2017.

52 Kementerian Pendayagunaan Aparatur Negara dan Reformasi Birokrasi Republik Indonesia, "Kesekretariatan Lembaga Negara" <https://www.menpan.go.id/site/kelembagaan/545kesekretariatan-lembaga-negara> diakses tanggal 10 Desember 2017.

${ }^{53}$ Lihat: (1) Kementerian Pendayagunaan Aparatur Negara dan Reformasi Birokrasi Republik Indonesia, dan UUD NRI 1945 sebagai pedoman utama yang tidak boleh dilanggar isinya.

Penelitian ini diharapkan dapat menjelaskan peran dan manfaat dari indeks internasional untuk Indonesia dalam konteks ketika indeks ini menjadi salah satu pedoman peraturan perundang-undangan di Indonesia. Indeks internasional yang dibahas pada penelitian ini hanya akan fokus dan terbatas pada indeks sebagai berikut: Ease of Doing Business, Global Competitiveness Index, dan Rule of Law Index. Dalam penelitian ini akan dijelaskan dampak positif dan negatif serta kelemahan dari tiga indeks tersebut. Walaupun yang dibahas terbatas hanya pada tiga indeks di

"Peraturan Perundang-[u]ndangan di Bidang Kelembagaan"

<https://www.menpan.go.id/site/kelembagaan/2198 -peraturan-perundang-undangan-di-bidang-

kelembagaan> diakses tanggal 10 Desember 2017;

(2) Kementerian Pendayagunaan Aparatur Negara dan Reformasi Birokrasi Republik Indonesia, "Pola Dasar Struktur Organisasi" <https://www.menpan.go.id/site/kelembagaan/2181pola-dasar-struktur-organisasi> diakses tanggal 10 Desember 2017; (3) Kementerian Pendayagunaan Aparatur Negara dan Reformasi Birokrasi Republik Indonesia, "Peta Titelatur Kementerian / Lembaga" $<$ https://www.menpan.go.id/site/kelembagaan/2166peta-tit

elatur-kementerian-lembaga> diakses tanggal 10 Desember 2017; dan (4) Kementerian Pendayagunaan Aparatur Negara dan Reformasi Birokrasi Republik Indonesia, "Kelembagaaan [sic!] Pemerintah" < https://www .menpan.go.id/site/kelembagaan/7574-

kelembagaaan-pemerintah> diakses tanggal 10 Desember 2017. 
atas, diharapkan penelitian ini juga dapat relevan untuk dijadikan salah satu sumber pembelajaran dan diskusi apabila Indonesia ingin menggunakan indeks internasional lainnya untuk dipedomani.

\section{Peran Indeks Internasional}

Ease of Doing Business 2018 mengukur kemudahan berbisnis di suatu perekonomian $^{54}$ dan memberikan peringkat kepada 190 perekonomian dunia termasuk Indonesia. ${ }^{55}$ Pengerjaan Ease of Doing Business dilakukan oleh staf World Bank ${ }^{56}$ dengan didukung oleh kontribusi pihak eksternal. Laporan Doing Business telah melibatkan lebih dari 43.000 profesional dari 190 perekonomian dalam menyediakan data untuk laporan Doing Business 15 tahun terakhir (dihitung dari Ease of Doing

\footnotetext{
54 Istilah "perekonomian” digunakan (bukan negara) dikarenakan dari 190 "perekonomian" tidak semuanya adalah negara yang diakui oleh United Nations (misalnya: Taiwan dan Hong Kong). Lihat: (1) World Bank, Doing Business 2018| Reforming to Create Jobs (n 29) 4; dan (2) United Nations, "Growth in United Nations membership, 1945present" $\quad<$ http://www.un.org/en/sections/memberstates/growth-united-natios-membership-1

945-present/index.html> diakses tanggal 21 Januari 2018. Istilah "perekonomian" juga digunakan dalam penelitian ini untuk konteks Global Competitiveness Index dan Rule of Law of Index.

55 Ibid, World Bank, Doing Business 2018 | Reforming to Create Jobs, 4.

56 Penting untuk diketahui bahwa berdasarkan laporan Doing Business 2018: penemuan, interpretasi, dan kesimpulan pada laporan Doing
}

Business 2018 ke belakang). ${ }^{57}$ Pada laporan Ease of Doing Business 2018 sendiri telah melibatkan lebih dari 13.000 profesional atau local experts dari berbagai macam latar belakang yaitu dari swasta dan pemerintah. $^{58}$

Terdapat 10 indikator $^{59}$ dalam menilai peringkat suatu negara dalam indeks Ease of Doing Business 2018. ${ }^{60}$ Sepuluh indikator tersebut adalah: (1) memulai suatu bisnis, (2) berurusan dengan perizinan konstruksi, (3) mendapatkan listrik, (4) mendaftarkan properti, (5) mendapatkan kredit, (6) melindungi investor minoritas, membayar pajak, (8) perdagangan lintas batas, (9) penegakan pelaksanaan kontrak, dan (10) penyelesaian kepailitan. ${ }^{61}$

Global Competitiveness Index Rankings 2017-2018 yang digerakkan oleh

Business 2018 belum tentu merupakan pandangan World Bank, Board of Executive Directors, dan pemerintah yang mereka wakili. Lihat: Ibid, pada halaman awal laporan. Lihat juga pada laporan lainnya (halaman awal) di catatan kaki nomor 34 .

${ }^{57}$ Ibid, 11 dan 17.

${ }^{58}$ Ibid, 17 dan 67-68.

59 Terdapat 1 "indikator" lainnya yaitu mengenai peraturan pasar ketenagakerjaan yang tidak dijadikan bahan penilaian peringkat namun datanya disajikan dalam Doing Business 2018. Lihat: bagian Contents sebelah kanan, 115-117, 206-207, dan 212. Lihat juga: World Bank Group, Doing Business 2018 | Reforming to Create Jobs | Economy Profile Indonesia (n 36) 127-131.

${ }^{60}$ Ibid, 12, 70-117, dan 167.

61 Ibid. Untuk alur dari aktivitas yang ada pada indikator Ease of Doing Business, lihat: Ibid, 2. 
World Economic Forum memberi peringkat terhadap daya saing suatu perekonomian dari total 137 perekonomian-termasuk daya saing Indonesia. $^{62}$ Global Competitiveness Index Rankings 2017-2018 memiliki 12 indikator atau pilar dalam melakukan penilaian peringkat. ${ }^{63}$ Pilar tersebut adalah (1) institusi, infrastruktur, (3) lingkungan ekonomi makro, (4) kesehatan dan pendidikan dasar, (5) pendidikan tinggi dan pelatihan, (6) keefesienan pasar barang, (7) keefesienan pasar buruh, (8) perkembangan pasar finansial, (9) kesiapan teknologi, (10) ukuran pasar, (11) kompleksitas bisnis, dan (12) inovasi. ${ }^{64}$ Data Global Competitiveness Index Rankings 2017-2018 berasal dari berbagai sumber yaitu antara lain World Economic Forum's Executive Opinion Survey, International Monetary Fund (IMF), World Bank, International Labour Organization (ILO), World Trade Organization (WTO), International Telecommunication Union (ITU), United Nations Educational, Scientific and Cultural

62 World Economic Forum, The Global Competitiveness Report 2017-2018 (n 37) ii, vii, ix, dan 12.

${ }^{63}$ Ibid, ix, 149, 317-332, dan 341-351.

${ }^{64}$ Ibid.

${ }^{65}$ Ibid, 11-12, 333-339, dan 341-351.

${ }^{66}$ World Justice Project, World Justice Project Rule of Law Index 2017-2018 (n 40) 6-7.
Organization (UNESCO), dan World Health Organization (WHO), Organisation for Economic Co-operation and Development (OECD), International Trade Centre, International Air Transport Association (IATA), dan Institutional Investor, LLC. ${ }^{65}$ Rule of Law Index adalah indeks yang dikerjakan oleh World Justice Project yang fokus antara lain menilai supremasi hukum suatu perekonomian di dunia termasuk di Indonesia. ${ }^{66}$ World Justice Project sendiri merupakan organisasi independen dan multidisiplin yang awalnya diinisiasi oleh American Bar Association pada tahun $2006 .{ }^{67}$ Rule of Law Index 20172018 melibatkan survei lebih dari 110.000 orang / survei rumah tangga dan 3.000 ahli di 113 perekonomian. ${ }^{68}$ Rule of Law Index mempunyai 8 faktor $^{69}$ yang dijadikan ukuran dalam penilaian indeks, yaitu: (1) pembatasan kekuatan pemerintah, (2) ketidakadaan korupsi, (3) keterbukaan pemerintah, (4) hak dasar, (5) pengaturan dan keamanan, (6) pelaksanaan regulasi, (7) keadilan perdata, dan (8) keadilan pidana. ${ }^{70}$

\footnotetext{
${ }^{67}$ Ibid, 190.

${ }^{68}$ Ibid, 156 dan 2.

${ }^{69}$ Faktor "keadilan informal" datanya dikumpulkan oleh World Justice Project namun tidak dimasukkan dalam penilaian peringkat Rule of Law Index. Lihat: Ibid, 9.

${ }^{70}$ Ibid, 8-13 dan 91.
} 
Penting untuk disampaikan, ukuran dari tiap indikator pada tiga indeks di atas masih dapat diuraikan lagi menjadi indikator yang lebih spesifik. ${ }^{71}$

Tiga indeks di atas erat kaitannya dengan reformasi regulasi. ${ }^{72}$ Untuk mendapatkan peringkat yang terdepan diperlukan suatu reformasi regulasi. Misalnya laporan Doing Business sejak dulu konsisten untuk mendorong terciptanya reformasi regulasi. ${ }^{73}$ Penilaian indikator dari laporan Doing Business erat kaitannya dengan regulasi bisnis yang baik, baik secara langsung maupun tidak langsung. ${ }^{74}$ Regulasi bisnis yang baik diharapkan dapat menumbuhkan perekonomian bukan justru menghambat perekonomian. ${ }^{75}$ Peningkatan peringkat di Global Competitiveness Index dan Rule of Law Index juga tidak dapat dilepaskan dari reformasi regulasi dikarenakan terdapat kaitan penilaian indikator dengan reformasi regulasi di suatu

\footnotetext{
${ }^{71}$ Untuk konteks Ease of Doing Business, lihat: (1) World Bank, Doing Business 2018 | Reforming to Create Jobs (n 29) 167 dan 70-115; dan (2) World Bank Group, Doing Business 2018 | Reforming to Create Jobs | Economy Profile Indonesia (n 36). Untuk konteks Global Competitiveness Index, lihat: World Economic Forum, The Global Competitiveness Report 2017-2018 (n 37) ix, 149, 317-332, dan 341-351. Untuk konteks Rule of Law Index, lihat: Ibid, World Justice Project, World Justice Project Rule of Law Index 2017-2018 (n 40) 8-13 dan 91.

72 "Regulasi" ruang lingkupnya lebih luas dari peraturan perundang-undangan.
}

perekonomian baik secara langsung maupun tidak langsung. ${ }^{76}$

Terdapat sejumlah hal positif apabila Indonesia menggunakan indeks Ease of Doing Business, Global Competitiveness Index, dan Rule of Law Index sebagai salah satu patokan dari kegiatan reformasi peraturan perundang-undangannya dengan tujuan praktis berupaya memperbaiki peringkatnya di indeks tersebut. Pertama, Indonesia dapat memperbandingkan posisinya dengan negara-negara lainnya sehingga Indonesia mengetahui saat ini berada di mana dan berusaha untuk lebih baik lagi dengan mengelola peraturan perundang-undangan ke arah yang tepat. Perbaikan peringkat ini dalam rangka meningkatkan standar internasional Indonesia di tingkat dunia pada bidang yang sesuai dengan tiga indeks internasional tersebut.

\footnotetext{
${ }^{73}$ World Bank, Doing Business 2018 | Reforming to Create Jobs (n 29) iv-v dan 1-3.

${ }^{74}$ Lihat: (1) Ibid, 11-12 dan 16; dan (2) World Bank Group, Doing Business 2018 | Reforming to Create Jobs | Economy Profile Indonesia (n 36).

${ }^{75}$ Dalam konteks Ease of Doing Business, lihat: Ibid, World Bank, Doing Business 2018 | Reforming to Create Jobs (n 29) 1-3.

76 Lihat: World Economic Forum, The Global Competitiveness Report 2017-2018 (n 37) 341-350; dan (2) World Justice Project, World Justice Project Rule of Law Index 2017-2018 (n 40) 10-13.
} 
Kedua, meningkatnya dan tingginya peringkat Indonesia pada indeks internasional tersebut diharapkan dapat meningkatkan perekonomian Indonesia sebagaimana disinggung di atas. $^{77}$ Tingginya peringkat suatu negara di Ease of Doing Business menunjukan negara tersebut ramah untuk melakukan bisnis, pada Global Competitiveness Index memperlihatkan negara tersebut dapat bersaing secara internasional, dan pada Rule of Law Index menjamin adanya kepastian hukum yang baik di negara tersebut. Tiga indeks internasional ini merupakan alat promosi yang baik untuk Indonesia di tingkat internasional dan domestik. Dengan tingginya peringkat di tiga indeks tersebut diharapkan masyarakat dalam dan luar negeri menjadi lebih percaya dan bersedia untuk berinvestasi dan membangun Indonesia. $^{78}$

Ketiga, kenaikan dan tingginya peringkat Indonesia merupakan bukti prestasi dan pertanggungjawaban pemerintah Indonesia dan juga seluruh lembaga lainnya kepada rakyat Indonesia

77 Dalam konteks Ease of Doing Business, lihat: World Bank, Doing Business 2018 | Reforming to Create Jobs (n 29) 1-3.

${ }^{78}$ Ibid, 19-20.

${ }^{79}$ World Bank, Doing Business 2018|Reforming to Create Jobs (n 29) mengutip Haggard dan Williamson (1994). dalam suatu hal tertentu sesuai dengan indeksnya. Hal yang harus dihindari adalah terjadinya "honeymoon period", yaitu periode di mana pemerintah hanya semangat untuk melakukan perubahan di awal saja ketika terpilih, namun tidak semangat lagi selang beberapa waktu kemudian setelah terpilih. ${ }^{79}$ Dalam konteks pemerintahan di era Presiden Jokowi kita telah melihat misalnya tren kenaikan indeks peringkat di Ease of Doing Business sebagaimana dijelaskan pada bab sebelumnya. ${ }^{80}$ Diharapkan Presiden Jokowi tetap konsisten sampai akhir masa jabatan, dan siapa pun presiden berikutnya dapat melanjutkan dan meningkatkan apa yang telah dilakukan oleh Presiden Jokowi. Presiden Jokowi juga perlu memperhatikan dan meningkatkan peringkat pada indeks lainnya seperti Rule of Law Index yang peringkatnya turun dari 61 (Rule of Law Index 2016) ke 63 (Rule of Law Index 2017-2018) ${ }^{81}$

Keempat, hal yang penting untuk diutarakan adalah diharapkan akan terjadi efek domino ketika terjadi reformasi peraturan perundang-undangan berbasis

\footnotetext{
${ }^{80}$ Lihat: Bab I.

${ }^{81}$ Lihat: (1) World Justice Project, World Justice Project Rule of Law Index 2016 (World Justice Project 2016) 21; dan World Justice Project, World Justice Project Rule of Law Index 2017-2018 (n 40) 16.
} 
indeks internasional ini. Reformasi peraturan perundang-undangan diharapkan dapat menimbulkan reformasi regulasi. Artinya produk hukum terkait regulasi di luar peraturan perundang-undangan, seperti: peraturan kebijakan, peraturan internal, dan keputusan yang terkait dengan pelaksanaan peraturan perundang-undangan dapat mendapatkan semangat dan konten yang sama yaitu berpedoman pada perbaikan peringkat di indeks internasional tersebut.

Selain dampak positif, terdapat juga resiko indeks internasional ini menimbulkan efek negatif atau komentar negatif. Pertama, menjadikan indeks internasional sebagai pedoman dapat saja menimbulkan tuduhan seperti "tidak nasionalis" atau "antek asing". Tuduhan ini dapat dibantah dengan paling tidak dua hal. Pertama, indeks internasional ini hanya dijadikan pedoman ketika tidak bertentangan dengan Pancasila dan UUD NRI 1945. Kedua, tujuan berpedoman pada indeks harus benar-benar dibuktikan secara konkret demi kepentingan Indonesia.

Kedua, bagaimana apabila seandainya terjadi pertentangan antara indeks

${ }^{82}$ Penting diketahui, Global Competitiveness Index juga menggunakan indeks Ease of Doing Business untuk sejumlah aspek penilaian indeks. Lihat: World Bank, Doing Business 2018 | Reforming to Create Jobs (n 29) 21. internasional tersebut. ${ }^{82}$ Solusi untuk ini adalah sama yaitu tetap berpegangan dengan Pancasila dan UUD NRI 1945. Harus dipilih mana yang lebih mendukung Pancasila dan UUD NRI 1945, serta yang mana yang benar-benar bermanfaat bagi kepentingan Indonesia.

Selain itu terdapat juga keterbatasan pada indeks internasional ini yang perlu dijelaskan pada penelitian ini. Misalnya dalam konteks Ease of Doing Business 2018, terdapat kekurangan seperti hanya fokus pada Jakarta dan Surabaya saja. ${ }^{83}$ Padahal Indonesia jauh lebih luas dari Jakarta dan Surabaya. ${ }^{84}$ Hal yang sama juga dalam konteks Rule of Law Index yang hanya menjangkau Jakarta, Surabaya, dan Bandung. ${ }^{85}$ Kedepannya pemerintah dapat saja mengembangkan indeks berbasis Ease of Doing Business dan Rule of Law Index yang menjangkau seluruh provinsi, kabupaten, dan kota di Indonesia demi kepentingan Indonesia. Dengan jangkauan yang lebih luas maka reformasi peraturan perundang-undangan dapat menyentuh

\footnotetext{
${ }^{83}$ Lihat: (1) Ibid, 14; dan (2) World Bank Group, Doing Business 2018 | Reforming to Create Jobs | Economy Profile Indonesia (n 36).

${ }^{84}$ World Bank, Doing Business 2018 | Reforming to Create Jobs (n 29) 14.

${ }^{85}$ World Justice Project, World Justice Project Rule of Law Index 2017-2018 (n 40) 162.
} 
sampai ke level peraturan di tingkat provinsi, kabupaten, dan kota.

Kekurangan lainnya Ease of Doing Business 2018 fokus pada sektor formal dan tidak menampilkan kondisi sektor informal. ${ }^{86}$ Hal ini apabila belum dapat dikembangkan oleh indeks Ease of Doing Business, dapat juga dimulai oleh pengembangan indeks oleh pemerintah dengan memasukkan aspek sektor informal. Lebih lanjut, reformasi regulasi dalam konteks seperti Ease of Doing Business tanpa didukung oleh supremasi hukum maka hanya menyajikan peringkat yang baik saja namun pada kenyataannya di lapangan tidak demikian. ${ }^{87}$ Oleh karena itu indeks internasional lainnya seperti Rule of Law Index dapat memainkan perannya sebagai pemberi informasi mengenai seberapa kuat kepastian hukum pada suatu perekonomian.

Penting untuk diketahui Rule of Law index 2017-2018 memiliki masalah dengan keterbatasan jumlah ahli yang dapat berdampak bagi penilaian terhadap suatu negara yang tidak memiliki ahli (meliputi akademisi dan praktisi) yang cukup. $^{88}$ Dalam konteks Indonesia, ahli yang

\footnotetext{
${ }^{86}$ World Bank, Doing Business 2018 | Reforming to Create Jobs (n 29) 14.

${ }^{87}$ Ibid.
}

memberikan kontribusi dalam Rule of Law Index 2017-2018 masih belum begitu banyak apabila dibandingkan perekonomian seperti Amerika Serikat, meskipun perlu diakui Indonesia telah unggul dibandingkan sejumlah perekonomian lainnya. ${ }^{89}$ Solusi untuk meningkatkan jumlah kontributor ahli Indonesia adalah pemerintah dan pemangku kepentingan lainnya aktif melakukan komunikasi kepada ahli terkait sesuai bidang indikator yang relevan untuk terlibat pada penilaian Rule of Law Index berikutnya.

Terdapat sejumlah cara untuk memperbaiki peringkat Indonesia pada tiga indeks internasional di atas. Pertama, Indonesia perlu menetapkan target yang jelas. Dalam konteks Ease of Doing Business, Presiden Jokowi menargetkan untuk masuk ke dalam 40 besar Ease of Doing Business sebagaimana disebut pada bab sebelumnya. ${ }^{90}$ Selanjutnya perlu ditentukan kapan tenggat waktu pencapaian target tersebut dan dibuat rencana komprehensif yang jelas untuk memastikan target dapat terpenuhi sesuai waktunya.

\footnotetext{
${ }^{88}$ World Justice Project, World Justice Project Rule of Law Index 2017-2018 (n 40) 160.

${ }^{89}$ Ibid, 173-174 dan 165-186.

${ }^{90}$ Lihat: Bab I.
} 


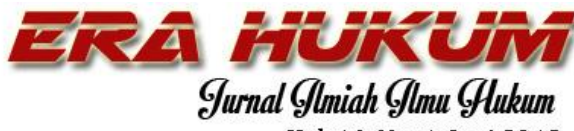

Vol 16, No. 1, Juni 2018

Handa S. Abidin

Pedoman Peraturan Perundang-undangan..

Kedua, Indonesia perlu melakukan studi banding terhadap negara-negara yang menduduki peringkat tinggi di indeks internasional tersebut. Kesuksesan mereka dalam mencapai peringkat tersebut perlu dipelajari dan disesuaikan dalam konteks Indonesia, khususnya terkait dalam rangka reformasi peraturan perundang-undangan. Dalam konteks Ease of Doing Business, Indonesia dapat belajar dari Selandia Baru ${ }^{91}$, Singapura $^{92}$, dan Denmark ${ }^{93}$ yang berada di 3 besar peringkat Ease of Doing Business 2018 secara umum $^{94}$ serta pada negara lain yang duduk di peringkat papan atas untuk indikator tertentu pada Ease of Doing Business 2018. ${ }^{95}$ Dalam konteks Global Competitiveness Index 2017-2018, Indonesia dapat belajar dari Swiss, Amerika Serikat, dan Singapura (peringkat 3 besar) serta perekonomian lain yang berada di papan atas pada indikator tertentu pada Global Competitiveness Index 2017-2018. ${ }^{96}$ Dalam konteks Rule of Law Index 2017-

91 World Bank Group, Doing Business 2018 | Reforming to Create Jobs | Economy Profile Singapore (World Bank Group).

92 World Bank Group, Doing Business 2018 | Reforming to Create Jobs | Economy Profile New Zealand (World Bank Group).

93 World Bank Group, Doing Business 2018 | Reforming to Create Jobs | Economy Profile Denmark (World Bank Group).

${ }^{94}$ World Bank, Doing Business 2018 | Reforming to Create Jobs (n 29) 4.
2018, Indonesia dapat mempelajari Denmark, Norwegia, dan Finlandia (peringkat 3 besar) serta perekonomian lain yang masuk pada papan atas di indikator tertentu pada Rule of Law Index 2017$2018 .{ }^{97}$

Ketiga, setelah mempelajari indikator dan turunan dari indeks internasional tersebut, Indonesia dapat memulai dari hal yang mudah untuk dilakukan terlebih dahulu dan yang paling memungkinkan untuk dilakukan terlebih dahulu. Misalnya cukup banyak perekonomian dalam konteks indeks Ease of Doing Business fokus pada pengurangan kompleksitas prosedur dan biaya terkait proses tersebut. ${ }^{98}$ Ambil contoh, Thailand. Sebelumnya untuk memulai bisnis di Thailand dibutuhkan 27,5 hari. ${ }^{99}$ Sekarang (berdasarkan laporan Doing Business 2018) hanya dibutuhkan 4,5 hari saja untuk memulai bisnis. ${ }^{100}$

Keempat, indikator indeks dapat berubah dan berkembang. Misalnya indeks

\footnotetext{
95 Ibid, 142-205, 35-38, dan 124-141.

96 World Economic Forum, The Global Competitiveness Report 2017-2018 (n 37) ix dan 326332, dan 42-315.

${ }^{97}$ World Justice Project, World Justice Project Rule of Law Index 2017-2018 (n 40) 16-17 dan 32-39.

98 World Bank, Doing Business 2018 | Reforming to Create Jobs (n 29) 22.

${ }^{99}$ Ibid.

${ }^{100}$ Ibid.
} 
Ease of Doing Business dimulai dengan 5 indikator di laporan Doing Business 2004 dan pada laporan Doing Business 2018 terdapat 10 indikator yang dijadikan penilaian peringkat Ease of Doing Business. ${ }^{101}$ Global Competitiveness Index juga memiliki indikator dan penilaian baru untuk indeksnya di tahun mendatang. ${ }^{102}$ Rule of Law Index juga dapat berubah dan berkembang. ${ }^{103}$ Indonesia harus selalu mengikuti perkembangan dan memiliki kemampuan untuk beradaptasi dengan cepat.

Kelima, apabila ingin mengejar kepentingan praktis jangka pendek, reformasi peraturan perundang-undangan bisa juga fokus di daerah yang dijadikan penelitian dan penilaian oleh indeks tersebut. Ease of Doing Business fokus di Jakarta dan Surabaya, sedangkan Rule of Law Index di Jakarta, Surabaya, dan Bandung. ${ }^{104}$ Diharapkan hal ini dapat menjadi langkah awal dan memberikan dampak positif kepada wilayah lainnya di Indonesia. Paling tidak peraturan di tingkat nasional dapat berubah menjadi lebih baik

\footnotetext{
101 Ibid, 68.

102 World Economic Forum, The Global Competitiveness Report 2017-2018 (n 37) 353-357 dan 361-373.

${ }^{103}$ World Justice Project, World Justice Project Rule of Law Index 2017-2018 (n 40) 158-159.
}

sehingga berdampak ke wilayah lain tersebut. Selain itu wilayah yang menjadi fokus penelitian dan penilaian indeks dapat dijadikan wilayah percontohan bagi wilayah lain terutama dalam konteks peraturan pada level daerah. Untuk Global Competitiveness Index penilaiannya agak berbeda karena indeks ini juga bergantung dari data atau indeks lainnya — sebagaimana dijelaskan di atas — untuk melakukan penilaian. ${ }^{105}$

Keenam, pembentukan tim khusus untuk mengawal reformasi peraturan perundang-undangan termasuk dalam kaitannya dengan berbagai indeks internasional terkait perlu dikaji lebih dalam keuntungan dan kerugiannya. Terkait dengan indeks Ease of Doing Business, sudah sejumlah perekonomian telah memiliki komite untuk melakukan reformasi regulasi. ${ }^{106}$ Dalam laporan Doing Business 2018 disebutkan Indonesia merupakan salah satu perekonomian yang memiliki komite tersebut. ${ }^{107}$ Posisi, bentuk, dan wewenang dari "komite" milik Indonesia ini perlu ditelusuri lebih lanjut dikarenakan keberadaan "komite" ini (jika

104 Lihat: (1) World Bank Group, Doing Business 2018 | Reforming to Create Jobs | Economy Profile Indonesia (n 36); dan (2) Ibid, 169.

${ }^{105}$ Lihat catatan kaki nomor 65.

106 World Bank, Doing Business 2018 | Reforming to Create Jobs (n 29) 18 dan Foreword. 107 Ibid. 
benar-benar sudah terbentuk) masih kurang terdengar.

Pembahasan mengenai dampak positif dan negatif termasuk kekurangan dari tiga indeks di atas serta rekomendasi untuk meningkatkan peringkat Indonesia pada tiga indeks tersebut dapat digunakan sebagai salah satu bahan pembelajaran dan diskusi apabila Indonesia ingin menggunakan indeks internasional lainnya — seperti indeks yang disinggung pada Bab I penelitian ini atau pun indeks internasional lain yang relevan-sebagai pedoman bagi peraturan perundang-undangan.

\section{Kesimpulan}

Indonesia tidak perlu takut untuk berkompetisi secara internasional. Menjadikan indeks skala internasional ini sebagai pedoman dalam peraturan

\section{DAFTAR PUSTAKA}

Astawa, M. I. G. P., dan Na'a, S., Dinamika Hukum dan Ilmu Perundangundangan di Indonesia (PT Alumni, Cetakan ke-2, 2012).

Badan Pengembangan dan Pembinaan Bahasa, Kementerian Pendidikan dan Kebudayaan Republik Indonesia (KBBI Daring), "Pe.do.man perundang-undangan mendatangkan sejumlah dampak positif bagi Indonesia. Namun demikian terdapat juga dampak negatif yang dapat muncul. Salah satu solusi penting untuk menghindari dampak negatif adalah dengan selalu konsisten berpegang teguh pada Pancasila dan UUD NRI 1945. Konsep penggunaan indeks internasional sebagai pedoman sebagaimana dijelaskan dalam penelitian ini bukan hanya terbatas untuk Ease of Doing Business, Global Competitiveness Index, dan Rule of Law Index saja. Tergantung dengan kebutuhan Indonesia, indeks internasional lainnya juga dapat dijadikan pedoman dengan memperhatikan aspek yang telah dijelaskan dalam penelitian ini yang terutamanya adalah wajib sejalan dan tidak bertentangan dengan Pancasila dan UUD NRI 1945.

/pêdoman/"

<https:kbbi.kemdikbud.go.i

d/entri/pedoman> diakses tanggal 9 Desember 2017.

<https://kbbi.kemdikbud.go.id/entri/si
stem> diakses tanggal 14 Januari 2018.

"Arah" ${ }^{1} "$ $<$ https://kbbi.kemdikbud.go.id/entri/ar ah> diakses tanggal 6 Januari 2018. 
Gwartney, J., Lawson, R., dan Hall, J., Economic Freedom of the World 2017 - Annual Report (Fraser Institute 2017).

Helliwell, J., Layard, R., dan Sachs, J. (editor), World Happiness Report 2017 (Sustainable Development Solutions Network 2017).

Indrati S., M. F., Ilmu Perundangundangan (1) (Jenis, Fungsi, dan Materi Muatan) (Dikembangkan dari Perkuliahan A. Hamid S. Attamimi) (Kanisius 2007).

Kementerian Pariwisata Republik Indonesia, "[']Siaran Pers['] Menpar Arief Yahya Membuka Wonderful Indonesia Co-Branding Forum (WICF)" (11 Agustus 2017) <http:/

/www.kem

enpar.go.id/asp?c=16\&id=3707>

diakses tanggal 10 Desember 2017.

Kementerian Pendayagunaan Aparatur Negara dan Reformasi Birokrasi Republik Indonesia, "Kelembagaaan Pemerintah" [sic!] $<$ https://www.menpan.go.id/site/kele mbagaan/7574-k

elembagaan-pemerintah> diakses tanggal 10 Desember 2017.

"Kementerian" <https://www.menpan.go.id/site/kele mbagaan/7577-kementerian-2> diakses tanggal 10 Desember 2017.

__, "Kesekretariatan Lembaga Negara" $<$ https://www.menpan.go.id/site/kele mbagaan/545- kesekretariatanlembaga-negara> diakses tanggal 10 Desember 2017.
—, "Lembaga Non Struktural" $<$ https://www.menpan.go.id/site/kele mbagaan/7571-lembag a-nonstruktural-2> diakses tanggal 10 Desember 2017.

—, "E. Lembaga Pemerintah Non Kementerian" $<$ https://www.menpan.go.id/site/kele mba gaan/7561-lembaga-pemerintahnon-kementerian-2> diakses tanggal 10 Desember 2017.

_-, "Lembaga Setingkat Menteri dan Lembaga Lain" $<$ https://www.menpan.go.id/site/kele mbagaan/547-lembaga-setingkatmenteri-dan-lembaga-lain> diakses tanggal 10 Desember 2017.

_, "Peraturan Perundang-Undangan di Bidang Kelembagaan" <https://www.menpan.go.id /site/kelembagaan/2198-peraturanperundang-undangan-di-bidangkelembagaan $>$ diakses tanggal 10 Desember 2017.

_, "Peta Titelatur Kementerian / Lembaga"

$<$ https://www.menpan.go.id/site/kele mbagaan /2166-peta-titelaturkementerian-lembaga $>$ diakses tanggal 10 Desember 2017.

,"Pola Dasar Struktur Organisasi" <https://www.menpan.go.id/site/kele mbagaan/2181-p ola-dasar-strukturorganisasi> diakses tanggal 10 Desember 2017.

Lubis, M. S., Ilmu Pengetahuan Perundang-undangan (CV Mandar Maju 2009). 
Oxford Dictionaries, "index" $<$ https://en.oxforddictionaries.com/def inition/index> diakses tanggal 7 Januari 2018.

Peraturan Presiden Republik Indonesia Nomor 54 Tahun 2017 tentang Unit Kerja Presiden Pembinaan Ideologi Pancasila (Ditetapkan: 19 Mei 2017 | Diundangkan: 23 Mei 2017).

Sekretariat Kabinet Republik Indonesia, "Intervensi Presiden RI Joko Widodo [p]ada KTT G-20, di Brisbane, Australia, 15 November 2014" (16 November 2014) <http:setkab.go.i d/intervensi-presiden-ri-joko-widodopada-ktt-g-20-di-brisbane-australia15-november-2

014/> diakses tanggal 12 Desember 2017.

_-, "Pengantar Presiden Joko Widodo pada Rapat Terbatas Masalah Ease of Doing Business [sic!] di Kantor Presiden, Jakarta, 20 Januari 2016" (20 Januari 2016) <http://se tkab.go.id/pengantar-presiden-jokowidodo-pada-rapat-terbatas-masalahease-of-doing-b usiness-di-kantor-presiden-jakarta-20januari-2016/> diakses tanggal 11 Desember 2017.

\section{, "Pengantar Presiden Joko Widodo} [p]ada Rapat Terbatas Mengenai Ease of Doing Business [sic!], 9 Mei 2016 Pukul 15.00 WIB, di Kantor Presiden Jakarta" (9 Mei 2016) $<$ http://setkab.go.id/pengantarpresiden-joko-widodo-pada-rapatterbatas-mengenai-easeof-doing-business-9-mei-2016-pukul15-00-wib-di-kantor-presiden- jakarta/> diakses tanggal 11 Desember 2017.

-, "Pengantar Presiden Joko Widodo pada Rapat Terbatas [M]engenai Lanjutan Pembahasan Reformasi Hukum, 17 Januari 2017, di Kantor Presiden, Jakarta" (17 Januari 2017) $<$ http://setkab.go.id/pengantarpresiden-joko-widodo-pada-rapatterbatas-mengenai-lanjutanpembahasan-reformasi-hukum-17januari-2017-di-kantor-presiden-ja karta/> diakses tanggal 11 Desember 2017.

- "Pengantar Presiden Joko Widodo pada Rapat Terbatas [M]engenai Pemantapan Pancasila, 19 Desember 2016, di Kantor Presiden, Jakarta" (19 Desember 2016) <http://s etkab.go.id/pengantar-presiden-jokowidodo-pada-rapat-terbatasmengenai-pemantapan-pancasila-19desember-2016-di-kantor-presidenjakarta/> diakses tanggal 6 Januari 2017.

-, "Pengantar Presiden Joko Widodo pada Sidang Kabinet Paripurna tentang Kapasitas Fiskal (Resource Envelopes) [sic!] dan Pagu Indikatif RAPBN Tahun 2018 serta Peningkatan Peringkat Ease of Doing Business [sic!] (EoDB) Tahun 2018, di Istana Negara, Jakarta, 15 Maret 2017” (15 Maret 2017)

<http://setkab.go.id/pengantarpresiden -joko-widodo-pada-sidang-kabinetparipurna-tentang-kapasitas-fiskalresource-envelope s-dan-pagu-indikatif-rapbn-tahun2018-serta-peningkatan-peringkatease-of-doing-busin 
ess-eodb/> diakses tanggal 11 Desember 2017.

__, "Pengantar Presiden Rapat Terbatas tentang Reformasi Hukum di Kantor Presiden, Selasa (11/10)" (11 Oktober 2016) <http://setkab.go.id/pengantarpresiden-rapat-terbatas -tentangreformasi-hukum-di-kantor-presidenselasa-1110/> diakses tanggal 12 Desember 2017.

—, "Sambutan Presiden Joko Widodo pada Jambore HIMPI [sic!] Perguruan Tinggi se-ASEAN, Senin, 23 Mei 2016 pukul 10.00 WIB, di Telkom University, Bandung, Jawa Barat" (23 Mei 2016)

$<$ http://setkab.go.id/sambutanpresiden-joko-widodo-pada-jambore himpi-perguruan-tinggi-se-aseansenin-23-mei-2016-pukul-10-00-wibdi-telkom-unvers ity-bandung-jawabarat/> diakses tanggal 7 Januari 2018.

, "Sambutan Presiden Joko Widodo saat Pencatatan Perdana Kontrak Investasi Kolektif - Efek Beragun Aset (KIK - EBA) Mandiri - PT Jasa Marga, Tbk. (JSMR 01) Surat Berharga Hak Atas Pendapatan Tol Jagorawi, Kamis, 31 Agustus 2017 Pukul 08.30 WIB di Gedung Bursa Efek Indonesia (BEI), Jakarta" (31 Agustus 2017) <http://setkab.go.id/s ambutan-presiden-joko-widodo-saatpencatatan-perdana-kontrak-investasikolektif-efek-beragun-aset-kik-ebamandiri-pt-jasa-marga-tbk-jsmr-01surat-berharga-hak-atas/> diakses tanggal 12 Desember 2017.

Transparency International, "Corruption Perceptions Index 2016" (Transparency International 2017).
Undang-Undang Dasar Negara Republik Indonesia Tahun 1945, Pembukaan, Alinea Keempat <http://www.dpr.go.id/jdih/uu1945> diakses tanggal 6 Januari 2018.

Undang-Undang Republik Indonesia Nomor 12 Tahun 2011 tentang Pembentukan Peraturan Perundangundangan (Disahkan: 12 Agustus 2011 | Diundangkan: 12 Agustus 2011).

United Nations Development Programme, Human Development Report 2016 Human Development for Everyone (United Nations Development Programme 2016).

_-, "Indonesia, Human Development Indicators" $<$ http://hdr.undp.org/en/countries/profi les /IDN> diakses tanggal 10 Desember 2017.

United Nations, "Growth in United Nations membership, 1945-present" $<$ http://www.un.org/ en/sections/membeer-states/growthunited-nations-membership-1945present/index.html > diakses tanggal 21 Januari 2018.

World Bank Group, Doing Business 2018 | Reforming to Create Jobs |Economy Profile Denmark (World Bank Group).

—_, Doing Business 2018|Reforming to Create Jobs | Economy Profile Indonesia (World Bank Group).

—_, Doing Business 2018|Reforming to Create Jobs | Economy Profile New Zealand (World Bank Group). 
- Doing Business 2018|Reforming to Create Jobs | Economy Profile Singapore (World Bank Group).

World Bank, A Guide to the World Bank (World Bank, 3rd Edition, 2011).

$-\underset{\text { Doing Business in } 2004 \text { Regulation }}{\text { Rerstanding }}$
(International Bank for Reconstruction and Development / the World Bank) (Copublication of the World Bank, the International Finance Corporation, dan Oxford University Press).

_ Doing Business in 2005 | Removing Obstacles to Growth (International Bank for Reconstruction and Development / the World Bank) (Copublication of the World Bank, the International Finance Corporation, dan Oxford University Press).

_- Doing Business in 2006 | Creating Jobs (International Bank for Reconstruction and Development / the World Bank) (Copublication of the World Bank dan the International Finance Corporation).

-, Doing Business 2007 | How to Reform (International Bank for Reconstruction and Development / the World Bank) (Copublication of the World Bank dan the International Finance Corporation).

, Doing Business 2008 (International Bank for Reconstruction and Development / the World Bank) (Copublication of the World Bank dan the International Finance Corporation).
Handa S. Abidin
_- Doing Business 2009 (International Bank for Reconstruction and Development / the World Bank) (Copublication of the World Bank, the International Finance Corporation, dan Palgrave Macmillan).

—, Doing Business 2010 | Reforming Through Difficult Times (International Bank for Reconstruction and Development / the World Bank) (Copublication of the Palgrave Macmillan, the World Bank dan the International Finance Corporation).

—_, Doing Business 2011 | Making a Difference for Entrepreneurs (International Bank for Reconstruction and Development / the World Bank) (Copublication of the World Bank dan the International Finance Corporation).

-, Doing Business 2012 | Doing Business in More Transparent World (International Bank for Reconstruction and Development / the World Bank) (Copublication of the World Bank dan the International Finance Corporation).

—_, Doing Business 2013 | Smarter Regulations for Small and MediumSize Enterprises (International Bank for Reconstruction and Development / the World Bank) (Copublication of the World Bank dan the International Finance Corporation)

Doing Business 2014
Understanding
and Regulations for Small (International Bank for Reconstruction and Development / the World Bank) (Copublication of the World Bank dan the International Finance Corporation). 
, Doing Business 2015 | Going Beyond Efficiency (International Bank for Reconstruction and Development / the World Bank).

__, Doing Business 2016 | Measuring Regulatory Quality and Efficiency (International Bank for Reconstruction and Development / the World Bank).

—, Doing Business 2017 | Equal Opportunity for All (International Bank for Reconstruction and Development / the World Bank).

—- Doing Business $2018 \mid$ Reforming to Create Jobs (International Bank for Reconstruction and Development / the World Bank).

World Economic Forum, The Global Competitiveness Report 2017-2018 (World Economic Forum 2017).

- The Travel \& Tourism Competitiveness Report 2017 - Paving the Way for a More Sustainable and Inclusive Future (World Economic Forum 2017).

World Justice Project, World Justice Project Rule of Law Index 2016 (World Justice Project 2016).

— World Justice Project Rule of Law Index 2017-2018 (World Justice Project 2018). 